\title{
Chemical and Mineral Composition of Amaranth (Amaranthus L.) Species Collected From Central Malawi
}

\author{
Nathan Aliel Kachiguma ${ }^{1}$, Weston Mwase $^{2}$, Moses Maliro ${ }^{2} \&$ Alex Damaliphetsa ${ }^{3}$ \\ ${ }^{1}$ Department of Agriculture Research Services, Lunyangwa Agriculture Research Station, Mzuzu, Malawi \\ ${ }^{2}$ Lilongwe University of Agriculture and Natural Resources, Bunda College Campus, Lilongwe, Malawi \\ ${ }^{3}$ GEF Small Grants Programme, UNDP, Lilongwe 3, Malawi
}

Correspondence: Nathan Aliel Kachiguma, Department of Agriculture Research Services, Lunyangwa Agricultural Research Station, P.O. Box 59, Mzuzu, Malawi. Tel: 265-999-801-255. E-mail: nkachiguma@yahoo.co.uk

\author{
Received: April 1, 2015 Accepted: May 29, 2015 Online Published: June 12, 2015 \\ doi:10.5539/jfr.v4n4p92 URL: http://dx.doi.org/10.5539/jfr.v4n4p92
}

\begin{abstract}
Chemical analysis and mineral composition of twenty accessions of grain and leaf Amaranth (Amaranthus L.) collected from different agro-ecological zones of Central Malawi were conducted according to the standards of Association of Official Analytical Chemistry (AOAC). Analysis of variance (ANOVA) and means were separated using least significance difference $(\mathrm{P} \leq 0.05)$ in Gen Stat version 15 . The analyses for grain Amaranth showed that moisture content ranges from 10.69 to $12.22 \%$ while ash content varied from 4.4 to $8.7 \%$. Elemental analyses in $\mathrm{mg} / 100$ grams on dry weight basis indicated that the grain had calcium (78.3 to 1004.6), iron (3.61 to 22.51), magnesium (44.31 to 97.38), potassium (267.8 to 473.6) and zinc (0.53 to 1.20). The mean differences for leaf chemical analyses were highly significant $(\mathrm{p}<0.001)$ with crude protein ranging from 13.37 to $23.27 \%$; ash (14.08 to $19.95 \%)$ and Vitamin C (30.3 to $117.79 \mathrm{mg} / 100 \mathrm{~g})$ while the mean mineral leaf analyses in $\mathrm{mg} / 100$ grams ranged from 14.84 to 31.17 for iron, 1.03 to 3.46 for zinc, 1512 to 2381 for calcium, 1320 to 1677 for potassium and 383.4 to 513.9 for magnesium. Generally the accessions from mid altitude area of Lilongwe showed highest values for both grain and leaf mineral analyses while accessions from the high altitude showed lower values. The results of this study provide evidence that local Amaranthus genotypes have appreciable amount of nutrients, minerals and vitamins important to meet dietary requirements of rural and urban communities in Malawi.
\end{abstract}

Keywords: Amaranth, accessions, chemical, characterization, agro-ecological zone, genotype

\section{Introduction}

Amaranthus belongs to the family Amaranthaceae with approximately 60 species that are recognized (Anjali et al., 2013). Some of the species include Amaranthus hypochondriacus, Amaranthus hybridus, Amaranthus cruentus and Amaranthus caudatus. Amaranths have been domesticated as leaf vegetables, fodder, potherbs or as ornamentals. Amaranth species are characterized by a high level of diversity and wide spectrum of adaptability to diverse environmental conditions in Malawi. Information on genetic as well as nutritional diversity among the species and their wild relatives is essential for efficient utilization of plant genetic resources such as crop improvement of Amaranth (Janovska et al., 2012). Several species of Amaranth are collected as non wood forest products from forests and wastelands. Even though many communities in Malawi harvest Amaranth from the wild such as forest sites, rural communities have made conscious efforts to conserve Amaranth around their homesteads and some plant the species as grain and leaf vegetables in crop fields and communal lands (Kwapata et al., 1992). Amaranth nutritional values are likely to vary widely due to influences of environment, genotype and adaptation to specific agro-ecological area under which the plant genotypes have evolved and are adapted (Makobo et al., 2010). There is growing ignorance among young people about the existence of indigenous vegetables that are nutritionally rich. The decline in consumption of indigenous vegetables such as Amaranth by rural and urban communities has resulted in poor diets and increased incidenceof nutritional deficiency disorders in many parts of Africa (Kwapata \& Maliro, 1995). Amaranth contribute to the nutritional well-being of rural people by providing the essential nutrients required for body growth and development and for prevention of diseases associated with nutritional disorders such as blindness due to vitamin A deficiency. In Malawi, leaves of 
Amaranth are eaten as spinach or green vegetables. The leaves boiled and mixed with groundnuts sauce are eaten as salad. The grain of Amaranthus hypochondriacus is pound and bottled and sold as immune boosters in different pharmacies and supermarkets in Malawi. Unlike conventional vegetables, there is inadequate documented information about nutrient and chemical composition of Amaranth grain and leaves. This study was commissioned to assess the nutritional and chemical composition of different accessions of Amaranth collected from different agro-ecological zones in Central Malawi as a starting point for domestication, selection and crop improvement.

\section{Materials and Methods}

\subsection{Source of Accessions}

Seed accessions were collected from five different sites in Lilongwe, three sites in Dedza and two sites in Kasungu district. Accession DN-LL-29-ExBunda (A. hypochondriacus) from Bunda was locally collected and selected in Malawi. The cultivar has been locally evaluated, it is promoted for vegetable production, it is very promising for grain production and is commonly called "HypoBunda" (Mwase, personal communication). Accession NM-LL-31-ExBunda is Green giant collected from the Bunda College Horticulture farm. Accessions were collected from farmland, wild, Bunda College (Horticulture Department seed stock) and Malawi Plant Genetic Resource Centre (MPGRC) at Chitedze Agriculture Research Station. One accession was freely provided by Kenya Agricultural Research Institute (KARI), Kakamega in Western Kenya and accessions from Malawi Plant Genetic Resource Centre were out sourced from Israel (Table 1).

Table 1. Geographical sites of collection of amaranth accessions for nutritional studies in Central Malawi

\begin{tabular}{|c|c|c|c|c|c|}
\hline Accession & Species & Collection site & Latitude & $\begin{array}{l}\text { Long } \\
{ }^{\circ} \mathrm{E}\end{array}$ & $\begin{array}{l}\begin{array}{l}\text { Elevation } \\
\text { category }\end{array} \\
\text { (m), }\end{array}$ \\
\hline DN-DZ-01 & A. cruentus & Dedza Centre & $14^{\circ} 01^{\prime} \mathrm{S}$ & $33^{\circ} 46^{\prime}$ & 1521 high altitude \\
\hline DN-DZ-06 & A. hybridus & Dedza, Fuel station & $14^{\circ} 23^{\prime} \mathrm{S}$ & $34^{\circ} 20^{\prime}$ & 1632 high altitude \\
\hline DN-DZ-08 & A. hybridus & Dedza, Golomoti & $14^{\circ} 24^{\prime} \mathrm{S}$ & $34^{\circ} 35^{\prime}$ & 558 low altitude \\
\hline DN-LL-10 & A. lividus & Lilongwe, Biwi & $13^{\circ} 59^{\prime} \mathrm{S}$ & $33^{\circ} 47^{\prime}$ & 1104 mid altitude \\
\hline DN-LL-13 & A. lividus & Lilongwe, Biwi & $13^{\circ} 59^{\prime} \mathrm{S}$ & $33^{\circ} 47^{\prime}$ & 1104 mid altitude \\
\hline DN-LL-19 & A. cruentus & Lilongwe, Area 24 & $14^{\circ} 01^{\prime} \mathrm{S}$ & $\begin{array}{l}33^{\circ} \\
48^{\prime}\end{array}$ & 1059 mid altitude \\
\hline DN-LL-22 & A. cruentus & Lilongwe, Area 24 & $14^{\circ} 01^{\prime} \mathrm{S}$ & $\begin{array}{l}33^{\circ} \\
48^{\prime}\end{array}$ & 1059 mid altitude \\
\hline DN-LL-24 & A. cruentus & Lilongwe, Area 24 & $14^{\circ} 01^{\prime} \mathrm{S}$ & $\begin{array}{l}33^{\circ} \\
48^{\prime}\end{array}$ & 1059 mid altitude \\
\hline DN-LL-25 & A. hybridus & Lilongwe, Njewa & $13^{\circ} 55^{\prime} \mathrm{S}$ & $33^{\circ} 41^{\prime}$ & 1115 , mid altitude \\
\hline DN-LL-27 & A. hybridus & Lilongwe, Njewa & $13^{\circ} 55^{\prime} \mathrm{S}$ & $33^{\circ} 41^{\prime}$ & 1115 , mid altitude \\
\hline DN-LL-28 & A. hybridus & Lilongwe, Njewa & $13^{\circ} 55^{\prime} \mathrm{S}$ & $33^{\circ} 41^{\prime}$ & 1115 , mid altitude \\
\hline NM-LL-29-ExBunda & & Lilongwe, Bunda & $14^{\circ} 10^{\prime} \mathrm{S}$ & $33^{\circ} 46^{\prime}$ & 1194, mid altitude \\
\hline NM-LL-30-ExKenya & A.hypochondriacus & Kenya, Kakamega & $0^{\circ} 17^{\prime} \mathrm{N}$ & $34^{\circ} 44^{\prime}$ & 1110 mid altitude \\
\hline \multicolumn{6}{|l|}{ DN-LL-31ExBunda } \\
\hline DN-KU-16 & A. hybridus & Kasungu & $13^{\circ} 02^{\prime} \mathrm{S}$ & $33^{\circ} 28^{\prime}$ & 1046 mid altitude \\
\hline DN-KU-17 & A. hybridus & Kasungu & $13^{\circ} 02^{\prime} \mathrm{S}$ & $33^{\circ} 28^{\prime}$ & 1046 mid altitude \\
\hline DN-KU-18 & A. hybridus & Kasungu & $13^{\circ} 02^{\prime} \mathrm{S}$ & $33^{\circ} 28^{\prime}$ & 1046 mid altitude \\
\hline $\begin{array}{l}\text { MW-2706-32 } \\
\text { MW-2706-38 }\end{array}$ & A. hypochondriacus & $\begin{array}{l}\text { Lilongwe, } \\
\text { Chitedze }\end{array}$ & $13^{\circ} 59^{\prime} \mathrm{S}$ & $33^{\circ} 38^{\prime}$ & 1097 mid altitude \\
\hline
\end{tabular}

\subsection{Experimental Site}

The analyses were carried out at Bunda College of Agriculture (Longitude ${ }^{\circ} \mathrm{E}$ : 033ํ⒍354'; Latitude ${ }^{\circ} \mathrm{S}$ : 
$\left.14^{\circ} 10.344\right)$. Chemical composition analyses were done in the Department of Home Economics and Human Nutrition laboratory while mineral analyses were done at Agricultural Research and Extension Trust (ARET) laboratory. Seeds of accessions that were collected were planted and raised in a green house at Bunda College of Agriculture.

\subsection{Experimental Design and Data Collection}

The experiment was laid out in a completely randomized design (CRD) replicated three times. Nine and twenty accessions were analysed for grain and leaf nutrient compositions respectively using standard analytical procedures of Association of Official Analytical Chemistry (AOAC). Data on grain and leaf chemical composition were determined for crude protein, Vitamin C, moisture and ash contents. Data on grain and leaf mineral content were determined for iron $(\mathrm{Fe})$, zinc $(\mathrm{Zn})$, calcium $(\mathrm{Ca})$, potassium $(\mathrm{K})$ and magnesium $(\mathrm{Mg})$ content.

\subsection{Sample Preparation}

Leaf samples of Amaranth were collected from seedlings six weeks after planting. The leaves were sun dried for two days until sufficiently crisped (Akubugwo et al., 2007). Moisture content, protein and ash analyses were conducted on the leaves. Moisture content was determined using an oven-drying method (Horwitz, 2000). Each dried sample was crushed and placed into airtight plastic bottles and kept at room temperature for subsequent analyses.

\subsection{Chemical Analysis}

For chemical analysis, aliquots were made from $0.5 \mathrm{~g}$ of sample in two replicates. Moisture, ash, crude protein were analysed following the recommended methods of the Association of Official Analytical Chemists (AOAC, 1997). The moisture content was determined using the oven drying methods of a $5 \mathrm{~g}$ representative sample at $105 \pm 1{ }^{\circ} \mathrm{C}$ for 4 hours while ash was determined by incineration of $5 \mathrm{~g}$ sample at $550{ }^{\circ} \mathrm{C}$ for 5 hours. Vitamin $\mathrm{C}$ (ascorbic acid) content determination was conducted by titration method according to AOAC (1997) and the method of Barakat et al. (1973). Crude protein was determined by the Kjeldahl method and Total Protein was calculated by multiplying the evaluated nitrogen by 6.25 using the following formula:

Percent $(\%)$ protein content $=\frac{[\mathrm{N} \times 14.007 \times(\mathrm{Vs}-\mathrm{Vb}) \times 6.25 \times 250] \times 100}{\mathrm{~W} \times 1000}$ Where:

$\mathrm{N}=$ Normality $(0.1)$ of standard $\mathrm{HCl}$ acid

$\mathrm{Vs}=$ Volume of standard $\mathrm{HCl}$ acid used totitrate a sample

$\mathrm{Vb}=$ Volume of standard $\mathrm{HCl}$ acid used toTitrate a blank

$\mathrm{W}=$ Weight $(\mathrm{g})$ of dry sample used

\subsection{Mineral Analysis}

Mineral elements comprising calcium, potassium, magnesium, iron and zinc were determined following the method by Shahidi et al (1999) with minor modifications. Sample preparation was done through drying to ash and then mineral content in diluted acid was determined by Atomic Absorption Spectrophotometer (AAS) (Horwitz, 2000). Porcelain crucibles were pre-heated at $550^{\circ} \mathrm{C}$ for 2 hours and then put in a desiccator to cool down to room temperature. Approximately $2 \mathrm{~g}$ of each sample was weighed and subjected to drying ash in porcelain crucibles at $550^{\circ} \mathrm{C}$ for 2 hours after which samples were dissolved in $5.0 \mathrm{ml}$ of $\mathrm{HNO}_{3} / \mathrm{HCL} / \mathrm{H}_{2} \mathrm{O}$ in a 1:2:3 ratio and heated on hot plate till disappearance of brown fumes. Contents of the crucibles were filtered using Whatman No.1 filter paper into $100 \mathrm{ml}$ volumetric flasks. Solutions in $100 \mathrm{ml}$ volumetric flasks were then filled to the mark and used for mineral analyses using Atomic Absorption Spectrophotometer (AAS). The standards, blank and sample solutions were then read on AAS at the following wavelengths: $248.3 \mathrm{~nm}$ for iron, 213.9 for zinc, $422.7 \mathrm{~nm}$ for calcium, $285.2 \mathrm{~nm}$ for magnesium and $766.5 \mathrm{~nm}$ for potassium. Calculations were done using the following formulas:

Iron and Zinc $(\mathrm{mg} / 100 \mathrm{~g}$ sample $)=\frac{\mathrm{Co} \times \mathrm{V} \times \mathrm{D} \times 100}{\mathrm{~W} \times \mathrm{P} \times 1000}$ Where:

$\mathrm{C}_{\mathrm{O}}=$ concentration of the sample

$\mathrm{V}=$ total volume, $\mathrm{ml}$

$\mathrm{D}=$ dilution factor

$\mathrm{W}=$ weight of sample, $\mathrm{g}$ 
$\mathrm{P}=$ sample solution taken, $\mathrm{ml}$

$1000=$ conversion of $\mathrm{ml}$ to 1

Calcium, Magnesium and Potassium $(\mathrm{mg} / 100 \mathrm{~g})=\frac{\mathrm{Co} \times \mathrm{V} \times \mathrm{D} \times 100}{\mathrm{~W} \times 1000}$ Where:

$\mathrm{C}_{\mathrm{O}}=$ concentration of the sample

$\mathrm{V}=$ total volume, $\mathrm{ml}$

$\mathrm{D}=$ dilution factor

$\mathrm{W}=$ weight of sample, $\mathrm{g}$

$1000=$ conversion of $\mathrm{ml}$ to 1

\subsection{Statistical Analysis}

Mean square variances were subjected to ANOVA using GenStat Statistical package $15^{\text {th }}$ Edition. Means were separated using Tukey's Honest Significant Difference Test in GenStat at 5\% probability level (Kehinde et al., 2013).

\section{Results}

\subsection{Grain Chemical Composition}

Table 2 shows chemical composition of grain of nine Amaranth accessions. There were significant differences among accessions for both moisture content $(\mathrm{p} \leq 0.05)$ and ash content $(\mathrm{p}<0.001)$. The highest moisture content was $12.22 \%$ for DN-DZ-01 high altitude accession and lowest was $10.69 \%$ for DN-LL-25 while mean was $11.58 \%$. Accession DN-LL-27 had the highest ash content of $8.73 \%$ while DN-KU-18 had lowest ash content of $4.41 \%$ and mean was $5.69 \%$.

Table 2. Chemical composition of grain of Amaranthus on dry weight basis

\begin{tabular}{lll}
\hline Accession & Moisture (\%) & Ash (\%) \\
\hline DN-DZ-01 & $12.22^{\mathrm{c}}$ & $4.93^{\mathrm{abc}}$ \\
DN-DZ-06 & $12.11^{\mathrm{bc}}$ & $5.25^{\mathrm{bcd}}$ \\
DN-DZ-08 & $12.06^{\mathrm{bc}}$ & $5.52^{\mathrm{cd}}$ \\
DN-LL-10 & $11.79^{\mathrm{bc}}$ & $5.89^{\mathrm{d}}$ \\
DN-KU-18 & $11.61^{\mathrm{bc}}$ & $4.41^{\mathrm{a}}$ \\
DN-LL-22 & $11.22^{\mathrm{ab}}$ & $6.74^{\mathrm{e}}$ \\
DN-LL-24 & $11.27^{\mathrm{bc}}$ & $4.74^{\mathrm{ab}}$ \\
DN-LL-25 & $10.69^{\mathrm{a}}$ & $4.99^{\mathrm{abc}}$ \\
DN-LL-27 & $11.22^{\mathrm{a}}$ & $8.73^{\mathrm{f}}$ \\
Mean & 11.58 & 5.69 \\
Se $( \pm)$ & 0.367 & 0.292 \\
CV (\%) & 3.2 & 5.1 \\
\hline
\end{tabular}

Means in the same column with similar letters were not significantly different $(\mathrm{P} \leq 0.05)$.

\subsection{Grain Mineral Composition}

Table 3 shows mineral composition of grain Amaranth accessions. There were significant differences among the accessions in iron, calcium, potassium and magnesium content $(\mathrm{p}<0.001)$ and zinc content $(\mathrm{P} \leq 0.05)$. The highest iron content was $22.51 \mathrm{mg} / 100 \mathrm{~g}$ for DN-LL-22 and lowest was $3.61 \mathrm{mg} / 100 \mathrm{~g}$ for DN-LL-25 while mean was $12.23 \mathrm{mg} / 100 \mathrm{~g}$. Accession DN-KU-18 had the highest zinc content of $1.20 \mathrm{mg} / 100 \mathrm{~g}$ followed by DN-LL-22 while DN-LL-25 had lowest zinc content of $0.53 \mathrm{mg} / 100 \mathrm{~g}$ and mean was $0.91 \mathrm{mg} / 100 \mathrm{~g}$. Accession DN-LL-27 had the highest calcium content of $1004.6 \mathrm{mg} / 100 \mathrm{~g}$ while the lowest was DN-LL-25 with 78.3 $\mathrm{mg} / 100 \mathrm{~g}$ and mean was $370.3 \mathrm{mg} / 100 \mathrm{~g}$. Accessions DN-LL-24 and DN-LL-27 had the highest potassium and 
magnesium content of 473.6 and $97.38 \mathrm{mg} / 100 \mathrm{~g}$ respectively while DN-LL-25 had the least in both potassium and magnesium content.

Table 3. Mineral composition of grain Amaranthus on dry weight basis (mg/100 g)

\begin{tabular}{llllll}
\hline Accession & Iron & Zinc & Calcium & Potassium & Magnesium \\
\hline DN-DZ-01 & $6.16^{\mathrm{ab}}$ & $0.74^{\mathrm{ab}}$ & $125.2^{\mathrm{ab}}$ & $267.8^{\mathrm{a}}$ & $50.74^{\mathrm{ab}}$ \\
DN-DZ-06 & $13.75^{\mathrm{cd}}$ & $1.00^{\mathrm{ab}}$ & $243.8^{\mathrm{abc}}$ & $290.6^{\mathrm{ab}}$ & $57.89^{\mathrm{ab}}$ \\
DN-DZ-08 & $10.91^{\mathrm{bc}}$ & $0.99^{\mathrm{ab}}$ & $601.5^{\mathrm{d}}$ & $444.8^{\mathrm{bcd}}$ & $90.56^{\mathrm{cd}}$ \\
DN-LL-10 & $13.66^{\mathrm{cd}}$ & $0.91^{\mathrm{ab}}$ & $440.2^{\mathrm{cd}}$ & $302.8^{\mathrm{abc}}$ & $57.33^{\mathrm{ab}}$ \\
DN-KU-18 & $8.76^{\mathrm{abc}}$ & $1.20^{\mathrm{b}}$ & $225.9^{\mathrm{abc}}$ & $290.5^{\mathrm{ab}}$ & $57.64^{\mathrm{ab}}$ \\
DN-LL-22 & $22.51^{\mathrm{e}}$ & $1.05^{\mathrm{ab}}$ & $287.4^{\mathrm{abc}}$ & $315.6^{\mathrm{ab}}$ & $59.69^{\mathrm{abc}}$ \\
DN-LL-24 & $11.51^{\mathrm{bc}}$ & $0.83^{\mathrm{ab}}$ & $325.7^{\mathrm{bc}}$ & $473.6^{\mathrm{d}}$ & $77.29^{\mathrm{bcd}}$ \\
DN-LL-25 & $3.61^{\mathrm{a}}$ & $0.53^{\mathrm{a}}$ & $78.3^{\mathrm{c}}$ & $236.0^{\mathrm{a}}$ & $44.31^{\mathrm{a}}$ \\
DN-LL-27 & $19.21^{\mathrm{de}}$ & $0.89^{\mathrm{ab}}$ & $1004.6^{\mathrm{e}}$ & $455.2^{\mathrm{cd}}$ & $97.38^{\mathrm{d}}$ \\
Mean & 12.23 & 0.91 & 370.3 & 341.9 & 65.87 \\
Se $( \pm)$ & 0.822 & 0.097 & 33.07 & 23.06 & 4.574 \\
CV $(\%)$ & 9.5 & 15.1 & 12.6 & 9.5 & 9.8 \\
\hline
\end{tabular}

Means with similar letters in the same column were not significantly different $(\mathrm{P} \leq 0.05)$.

\subsection{Leaf Chemical Composition}

There were significant differences $(\mathrm{p}<0.001)$ between mean treatments for crude protein, vitamin $\mathrm{C}$, moisture and ash (Table 4). The highest protein content was $23.27 \%$ for DN-KU-18 and followed by $21.50 \%$ for DN-LL-29-ExBunda (Hypo-Bunda). DN-DZ-08 had the least protein content of $13.37 \%$ while the mean was 18.13\%. Accession DN-DZ-01 had the highest vitamin C content of $117.79 \mathrm{mg} / 100 \mathrm{~g}$ followed by DN-LL-29-ExBunda (Hypo-Bunda) $(115.57 \mathrm{mg} / 100 \mathrm{~g})$. The lowest vitamin $\mathrm{C}$ content was for NM-LL-31-ExBunda (30.30 mg/100 g). Accession DN-LL-27 recorded the highest moisture content of 4.61\%, while DN-LL-25 had the least moisture content of $1.36 \%$ and mean was $2.91 \%$. Accession DN-LL-24 had the highest ash content of $19.95 \%$ while DN-DZ-01 had the lowest ash content of $14.08 \%$. 
Table 4. Chemical composition of Amaranth leaves on dry matter basis

\begin{tabular}{|c|c|c|c|c|}
\hline Accession & Crude Protein (\%) & Vitamin C (mg/100 g) & Moisture (\%) & Ash (\%) \\
\hline DN-DZ-01 & $18.90^{\text {efgh }}$ & $117.79^{j}$ & $3.72^{\mathrm{gh}}$ & $14.08^{\mathrm{a}}$ \\
\hline DN-DZ-06 & $20.16^{\mathrm{gh}}$ & $88.94^{\mathrm{hi}}$ & $2.47^{\mathrm{bcd}}$ & $17.29^{\operatorname{defg}}$ \\
\hline DN-DZ-08 & $13.37^{\mathrm{a}}$ & $52.56^{\mathrm{cd}}$ & $4.46^{\mathrm{ij}}$ & $14.14^{\mathrm{a}}$ \\
\hline DN-LL-10 & $19.97^{\mathrm{gh}}$ & $86.45^{\mathrm{hi}}$ & $2.85^{\mathrm{de}}$ & $14.77^{\mathrm{ab}}$ \\
\hline DN-LL-13 & $20.81^{\mathrm{hi}}$ & $52.33^{\mathrm{cd}}$ & $3.37^{\mathrm{fg}}$ & $16.88^{\text {bcdefg }}$ \\
\hline DN-KU-16 & $15.42^{\mathrm{abcd}}$ & $64.33^{\mathrm{ef}}$ & $2.76^{\mathrm{cde}}$ & $17.49^{\mathrm{efg}}$ \\
\hline DN-KU-17 & $18.79^{\mathrm{efgh}}$ & $79.80^{\mathrm{gf}}$ & $2.72^{\text {cde }}$ & $15.64^{\text {abcde }}$ \\
\hline DN-KU-18 & $23.28^{\mathrm{i}}$ & $51.84^{\mathrm{bcd}}$ & $3.40^{\mathrm{fg}}$ & $17.91^{\mathrm{fg}}$ \\
\hline DN-LL-19 & $19.92^{\mathrm{gh}}$ & $48.81^{\mathrm{bcd}}$ & $2.43^{\mathrm{bcd}}$ & $18.51^{\mathrm{gh}}$ \\
\hline DN-LL-22 & $14.69^{\mathrm{abc}}$ & $44.30^{\mathrm{bc}}$ & $3.78^{\mathrm{gh}}$ & $15.67^{\text {abcde }}$ \\
\hline DN-LL-24 & $17.16^{\text {cdef }}$ & $48.93^{\mathrm{bcd}}$ & $3.15^{\mathrm{ef}}$ & $19.95^{\mathrm{h}}$ \\
\hline DN-LL-25 & $19.74^{\mathrm{fgh}}$ & $66.49^{\mathrm{ef}}$ & $1.36^{\mathrm{a}}$ & $18.37^{\mathrm{gh}}$ \\
\hline DN-LL-27 & $14.14^{\mathrm{ab}}$ & $93.70^{\mathrm{i}}$ & $4.61^{\mathrm{j}}$ & $15.06^{\mathrm{abc}}$ \\
\hline DN-LL-28 & $19.01^{\mathrm{efgh}}$ & $58.49^{\mathrm{de}}$ & $2.52^{\mathrm{bcd}}$ & $15.77^{\text {abcde }}$ \\
\hline DN-LL-29-ExBunda & $21.50^{\mathrm{hi}}$ & $115.57^{\mathrm{j}}$ & $1.60^{\mathrm{a}}$ & $17.65^{\mathrm{efg}}$ \\
\hline NM-LL-30-ExKenya & $14.48^{\mathrm{abc}}$ & $58.78^{\mathrm{de}}$ & $4.41^{\mathrm{ij}}$ & $16.78^{\text {bcdefg }}$ \\
\hline NM-LL-31-ExBunda & $15.90^{\mathrm{abcd}}$ & $30.30^{\mathrm{a}}$ & $2.14^{\mathrm{b}}$ & $17.18^{\text {cdefg }}$ \\
\hline MW-2706-32 & $17.59^{\operatorname{defg}}$ & $72.32^{\mathrm{fg}}$ & $4.04^{\mathrm{hi}}$ & $15.95^{\text {abcdef }}$ \\
\hline MW-2731-34 & $19.40^{\mathrm{fgh}}$ & $55.78^{\text {cde }}$ & $3.35^{\mathrm{fg}}$ & $15.15^{\mathrm{abc}}$ \\
\hline MW-2732-35 & $19.99^{\mathrm{gh}}$ & $66.43^{\text {ef }}$ & $2.37^{\mathrm{bc}}$ & $15.22^{\mathrm{abcd}}$ \\
\hline Mean & 18.30 & 66.40 & 3.08 & 16.43 \\
\hline $\operatorname{Se}( \pm)$ & 1.150 & 6.194 & 0.145 & 0.876 \\
\hline CV (\%) & 6.3 & 9.3 & 6.7 & 5.3 \\
\hline
\end{tabular}

Means with similar letters in the same column were not significantly different at $5 \%$ of probability level.

\subsection{Leaf Mineral Composition}

Mean values for mineral content of Amaranth accessions are presented in Table 5. There were significant differences among accessions in terms of iron, zinc, calcium, potassium and magnesium content $(\mathrm{p}<0.001)$. The highest iron content was $31.17 \mathrm{mg} / 100 \mathrm{~g}$ for DN-KU-17 Amaranthus hybridus from mid altitude areas of Kasungu while the lowest was $14.84 \mathrm{mg} / 100 \mathrm{~g}$ for DN-DZ-06 (Amaranthus hybridus) from high altitude areas. Accession DN-DZ-01 (A. cruentus) had the highest zinc content of $3.46 \mathrm{mg} / 100 \mathrm{~g}$ while DN-LL-10 had lowest zinc content of $1.03 \mathrm{mg} / 100 \mathrm{~g}$. The highest calcium content of $2381 \mathrm{mg} / 100 \mathrm{~g}$ was obtained from NM-LL-31-ExBunda while the lowest was DN-LL-28 with $1512 \mathrm{mg} / 100 \mathrm{~g}$ and mean was $2007 \mathrm{mg} / 100 \mathrm{~g}$. Accession DN-LL-22 had the highest potassium content of $1677 \mathrm{mg} / 100 \mathrm{~g}$ followed by DN-KU-19 with 1658 $\mathrm{mg} / 100 \mathrm{~g}$ and lowest was DN-KU-18 with $1320 \mathrm{mg} / 100 \mathrm{~g}$. Accession DN-KU-19 had the highest magnesium content of $513.9 \mathrm{mg} / 100 \mathrm{~g}$ and DN-DZ-06 had the least magnesium content of $383.4 \mathrm{mg} / 100 \mathrm{~g}$ while the mean was $462.0 \mathrm{mg} / 100 \mathrm{~g}$. 
Table 5. Mineral composition of leaves of Amaranth on dry weight basis ( $\mathrm{mg} / 100 \mathrm{~g})$

\begin{tabular}{|c|c|c|c|c|c|}
\hline Accession & Iron $(\mathrm{Fe})$ & Zinc (Zn) & Calcium (Ca) & Potassium (K) & Magnesium $(\mathrm{Mg})$ \\
\hline DN-DZ-01 & $17.26^{\mathrm{bcd}}$ & $3.46^{\mathrm{j}}$ & $1984^{\mathrm{cd}}$ & $1598^{\text {hijk }}$ & $470.9^{\text {cdefg }}$ \\
\hline DN-DZ-06 & $14.84^{\mathrm{a}}$ & $1.26^{\mathrm{cd}}$ & $1612^{\mathrm{ab}}$ & $1349^{\mathrm{ab}}$ & $383.4^{\mathrm{a}}$ \\
\hline DN-DZ-08 & $16.63^{b c}$ & $1.36^{\mathrm{de}}$ & $2332^{\mathrm{h}}$ & $1608^{\mathrm{hijk}}$ & $491.1^{\mathrm{efg}}$ \\
\hline DN-LL-10 & $23.50^{\mathrm{i}}$ & $1.03_{\mathrm{a}}$ & $2028^{\text {cde }}$ & $1563^{\text {fghijk }}$ & $478.7^{\text {defg }}$ \\
\hline DN-LL-13 & $15.63^{\mathrm{ab}}$ & $1.36_{\mathrm{de}}$ & $2354^{\mathrm{h}}$ & $1473^{\text {cdefg }}$ & $507.2^{\mathrm{fg}}$ \\
\hline DN-KU-16 & $18.91^{\mathrm{ef}}$ & $1.84_{\mathrm{h}}$ & $1924^{\mathrm{cd}}$ & $1436^{\text {abcde }}$ & $462.0^{\text {bcdefg }}$ \\
\hline DN-KU-17 & $31.17^{\mathrm{k}}$ & $1.15^{\mathrm{abc}}$ & $2028^{\text {cde }}$ & $1476^{\text {cdefg }}$ & $466.9^{\text {bcdefg }}$ \\
\hline DN-KU-18 & $16.80^{\mathrm{bcd}}$ & $2.87^{\mathrm{i}}$ & $2162^{\text {efg }}$ & $1320^{\mathrm{a}}$ & $486.4^{\mathrm{efg}}$ \\
\hline DN-LL-19 & $25.49^{j}$ & $1.84^{\mathrm{h}}$ & $2251^{\text {fgh }}$ & $1658^{i k}$ & $513.9^{\mathrm{g}}$ \\
\hline DN-LL-22 & $27.06^{\mathrm{j}}$ & $1.50^{\mathrm{ef}}$ & $2255^{\mathrm{fgh}}$ & $1677^{\mathrm{k}}$ & $468.7^{\text {cdefg }}$ \\
\hline DN-LL-24 & $20.16^{\mathrm{fg}}$ & $3.02^{\mathrm{i}}$ & $1883^{c}$ & $1539^{\text {efghij }}$ & $490.9^{\mathrm{efg}}$ \\
\hline DN-LL-25 & $17.34^{\text {bcde }}$ & $1.40^{\mathrm{de}}$ & $1599^{\mathrm{ab}}$ & $1422^{\text {abcde }}$ & $419.5^{\mathrm{abc}}$ \\
\hline DN-LL-27 & $17.78^{\text {cde }}$ & $1.25^{\mathrm{bcd}}$ & $1952^{\text {cd }}$ & $1592^{\text {ghijk }}$ & $450.5^{\text {bcde }}$ \\
\hline DN-LL-28 & $15.51^{\mathrm{ab}}$ & $1.05^{\mathrm{ab}}$ & $1512^{\mathrm{a}}$ & $1468^{\text {bcdef }}$ & $431.9^{\mathrm{abcd}}$ \\
\hline DN-LL-29-ExBunda & $18.61^{\text {edf }}$ & $2.83^{\mathrm{i}}$ & $2316^{\mathrm{gf}}$ & $1539^{\text {efghi }}$ & $484.4^{\mathrm{defg}}$ \\
\hline NM-LL-30-ExKenya & $14.21^{\mathrm{f}}$ & $1.60^{\mathrm{fg}}$ & $1647^{\mathrm{ab}}$ & $1337^{\mathrm{a}}$ & $418.0^{\mathrm{ab}}$ \\
\hline NM-LL-31-ExBunda & $22.60^{\mathrm{hi}}$ & $1.87^{\mathrm{h}}$ & $2381^{\mathrm{h}}$ & $1414^{\mathrm{abcd}}$ & $479.6^{\operatorname{defg}}$ \\
\hline MW-2706-32 & $21.44^{\mathrm{gh}}$ & $1.76^{\mathrm{gh}}$ & $2071^{\text {de }}$ & $1329^{\mathrm{a}}$ & $458.5^{\text {bcdef }}$ \\
\hline MW-2731-34 & $18.57^{\mathrm{def}}$ & $1.07^{\mathrm{abc}}$ & $1695^{\mathrm{b}}$ & $1496^{\text {defgh }}$ & $414.6^{\mathrm{ab}}$ \\
\hline MW-2732-35 & $22.82^{\mathrm{hi}}$ & $1.72^{\mathrm{gh}}$ & $2149^{\mathrm{ef}}$ & $1375^{\mathrm{abc}}$ & $462.4^{\text {bcdefg }}$ \\
\hline Mean & 19.82 & 1.76 & 2007 & 1483 & 462.0 \\
\hline $\operatorname{Se}( \pm)$ & 0.555 & 0.062 & 48.4 & 35.7 & 15.69 \\
\hline CV (\%) & 4.0 & 5.0 & 3.4 & 3.4 & 4.8 \\
\hline
\end{tabular}

Means with similar letters in the same column were not significantly different at $5 \%$ probability level.

\section{Discussion}

\subsection{Grain Chemical and Mineral Composition}

Moisture analysis is fundamental and data are used to express results of other analytical determinations on a uniform dry matter basis. The values of moisture content for Amaranth accessions are within the ranges reported for Amaranthus hybridus and other indigenous leafy vegetables (Chitsulo, 2013). Accessions from the cool wet high altitude area (DN-DZ-01 and ND-DZ-06) had significantly highest moisture content followed by accession from the hot dry low altitude area (DN-DZ-08) and then those from the warm wet mid-altitude agro-ecological areas. Perhaps seeds of genotypes adapted to the cool wet high-altitude areas were collected with relatively higher moisture content and that the genotypes tend to lose moisture slowly. However, these seed moisture content results were consistent with the recommended seed moisture content of 9 to $12 \%$ by O'Brien and Price (2008). Similar moisture profile of seed accessions of Amaranth were reported by Erum et al. (2012). The average ash content for Amaranth accessions are lower than those reported by Akubugwo et al. (2007) and Asaolu et al. (2012). However, ash content values are comparable with values in indigenous vegetables such as Corchorus olitorius, Cleome gynandra and Hibiscus sabdariffa (Patricia et al., 2014). Ash content is an index of mineral content in a plant material. Accessions from the warm wet mid-altitude areas had significantly higher levels of ash while those from high altitude areas had low ash and other mineral content. This confirms that Amaranth accessions from mid altitude of Lilongwe and Kasungu had high ash and mineral content than those from Dedza which is a high altitude agro-ecological zone. Accessions with high moisture content had similar growth characteristics and were of erect growth habit. The results suggest that the accessions share common 
ancestry and that there could be high flow of genetic material among the cool wet high altitude areas, warm wet mid-altitude areas and the hot dry low altitude areas. The mean crude protein content of Amaranth accessions (18.30\%) was within the values reported by Akubugwo et al. (2007). Amaranth accessions from mid altitude areas of Kasungu (DN-KU-18) followed by accession from Lilongwe (DN-LL-29) had the highest values of crude protein while those from low altitude of Dedza Golomoti DN-DZ-08 had the lowest values of crude protein $(13.37 \%)$. Accessions from the warm wet mid-altitude areas (DN-KU-18, DN-LL-13 and ND-LL-29-ExBunda) had highest protein content. Proteins are an abundant component in all cells, and almost all except storage proteins are important for biological functions and cell structure (Nielsen, 2003). Protein values are almost similar to the results reported by Janovska et al. (2012) while Pandey and Singh (2010) observed relatively lower content of protein. However, the crude protein levels are within acceptable levels required for provision of nutrition to human kind. According to Ali (2009) plant foods that provides more than $12 \%$ of its calorific value from protein are considered a good source of protein. Therefore, the levels of crude protein for amaranth accessions suggests that all the Amaranth accessions studied are good sources of protein. The protein content of the Amaranth accessions in this study are higher than the protein content of commercial vegetables with the exception of certain legumes as observed by Kruger et al. (1998). Amaranthus species provide approximately $12 \%$ of the recommended dietary allowance (RDA) for protein and this agrees with findings by Maundu et al. (1999).

Amaranth genotypes from warm wet mid-altitude areas (DN-LL-22 and DN-LL-27) had significantly higher iron content and the values are comparable with the recommended human dietary intake of $15 \mathrm{mg}$ (Lenntech, 2013) suggesting that genotypes from the warm wet mid-altitude areas can be a good dietary source of iron. The least iron content was found in accessions from the warm middle altitude agro-ecological zone. However, grain iron content levels are lower than the suggested supplementation in pregnant women of $30 \mathrm{mg}$ to $60 \mathrm{mg}$ elemental iron/day (World Health Organization, 2012). The accessions from the warm wet mid-altitude area of Kasungu (DN-KU-18) had relatively high zinc content of $1.20 \mathrm{mg} / 100 \mathrm{~g}$. For other mineral content like calcium, potassium and magnesium, accessions from the warm wet mid-altitude and the hot dry low-altitude areas (DN-LL-27, DN-LL-24 and DN-DZ-08) had high content, while accession DN-LL-25 from the warm wet mid-altitude area had the least content in all the minerals. Variations in chemical composition of grain and leafy vegetables are influenced by farming practices, soil health and prevailing environmental conditions. However, results for soil analysis proved to be rich in mineral nutrients necessary to support plant growth. Mohammed and Sharif (2011) argued that differences in mineral content of vegetable plants might be due to soil composition or rate of uptake of minerals by individual plants of specific genotypes. Being an essential micronutrient, Amaranth genotypes should be improved to increase Amaranth grain nutritional content uptake of zinc from the soil. The results suggest presence of genotypes capable of utilising $\mathrm{Ca}, \mathrm{K}$ and $\mathrm{Mg}$ from the soil in the warm wet middle altitude and the hot dry low altitude agro-ecological zones, as compared to the cool wet high altitude agro-ecological areas. The highest calcium content was comparable to the recommended daily intake of $1000 \mathrm{mg}$ (Lenntech, 2013). However, the grain calcium content levels are much lower than the suggested supplementation in pregnant women of $1500 \mathrm{mg}$ to $2000 \mathrm{mg}$ elemental calcium/day (WHO, 2013). The results suggest that local genotypes from the middle and low altitude agro-ecological zones are however, still a good dietary source of calcium.

\subsection{Leaf Chemical and Mineral Composition}

Accessions from the cool wet high-altitude areas and the warm wet mid-altitude areas (DN-DZ-01, DN-LL-29-ExBunda, DN-LL-27 and DN-DZ-06) had relatively high vitamin C content than accessions from the hot dry low altitude agro-ecological area. Vitamin C content values would meet the recommended adult dietary intake of 45 to $70 \mathrm{mg} /$ day (World Health Organization and Food Agriculture Organization of the United Nations, 2004). Leaf ash content was higher than grain ash content probably reflecting high mineral deposits in leaves than in Amaranth grain. Sharma et al. (2012) explained that high ash content in leaves is a reflection of high deposits of mineral elements. Asaolu et al. (2012) reported similar content of Amaranth ash but with very high protein content while Silva et al. (2000) reported relatively high content of both ash and protein. The differences in mineral composition in leaf and grain reported by various researchers may be attributed to differences in genotypes and agro-ecological areas various genotypes are adapted to. Generally accessions from the warm wet mid-altitude areas showed high nutritional content of protein, vitamin $\mathrm{C}$, moisture and ash with remarkable differences among accessions and across the agro-ecological zones. Acidic to moderately acidic soil is also a general characteristic of the warm and wet mid-altitude areas which might have an influence to genotypes adapted to the middle altitude agro-ecological zone. However, O'Brien and Price (2008) recommended neutral to basic soils which are usually fertile and ideal for production of Amaranth. Accession DN-LL-29-ExBunda 
(Hypo-Bunda) from the warm and wet mid-altitude area, had consistent and relatively high nutritional content of protein, vitamin $C$ and ash. This could be attributed to intensive selection on the accession since 1992 to date that has found Hypo-Bunda as the best genotype for promotion due to high nutritional content and preference by farming communities. Accessions with high protein, vitamin C, moisture and ash contents were of erect growth habit, probably signifying close relatedness of the genotypes.

The genotype from the warm wet mid-altitude area (DN-KU-17) had the highest iron content of $31.17 \mathrm{mg} / 100 \mathrm{~g}$. The least iron content was for the genotype from the cool wet high-altitude area DN-DZ-06 (14.84 mg/100 g). The results suggest presence of wide diversity of genotypes rich in iron within the warm wet middle altitude and the cool high altitude agro-ecological zones. Iron content values are comparable to recommended daily iron intake of $15 \mathrm{mg}$ (Lenntech, 2013) suggesting that leaves of Amaranth genotypes from Central Region of Malawi are a good dietary source of iron. However, the leaf iron content levels are lower than the suggested supplementation in pregnant women of $30 \mathrm{mg}$ to $60 \mathrm{mg}$ elemental iron/day (WHO, 2012). Accession from the cool wet high-altitude agro-ecological zone DN-DZ-01 had the highest zinc content $(3.46 \mathrm{mg} / 100 \mathrm{~g})$ suggesting that there is need to improve zinc uptake from the soil to concentrate zinc content in the plant. It is expected that wide diversity of genotypes with high zinc content would be found within the cool high altitude and the warm middle altitude agro-ecological zones. The leaf calcium content levels would meet suggested supplementation in pregnant women of $1500 \mathrm{mg}$ to $2000 \mathrm{mg}$ elemental calcium/day (WHO, 2013). The results suggest presence of genotypes with reasonable amounts of calcium and potassium to be found within the warm wet mid-altitude agro-ecological zone. Wide diversity of genotypes rich in magnesium content would be expected across the cool wet high-altitude and the warm wet mid-altitude agro-ecological zones. Similar values for iron, zinc and magnesium were obtained by Akubugwo et al. (2007), however low content for potassium and calcium was also reported. Similar content of calcium content was reported by Makobo et al. (2010) however it was at three weeks old contrary to this study which was done at six weeks old. Most accessions with high contents of leaf minerals were of erect growth habit signifying close relatedness of the genotypes. The variation of the results of different studies could also be due to different genotypes, farming practices, methods for analysis, soil types and environmental conditions the genotypes were growing. The results of leaf and grain nutritional analysis have shown that local accessions of Amaranthus species have demonstrated significant high mineral content as compared to introduced accessions.

\section{Conclusion}

Our data shows that the leaves and grain of Amaranthus species contain appreciable amounts of proteins, vitamin $\mathrm{C}$ and mineral elements. There is wide nutritional diversity of Amaranth genotypes across the three agro-ecological zones in Central Malawi. Wide nutrition diversity has also been observed within the warm wet mid-altitude agro-ecological zone. Amaranths leaves have shown to have more nutrition content than grain. The species Amaranthus hybridus has shown superior levels of ash, calcium, iron and phosphorous while Amaranthus cruentus is higher is vitamin C. Local accessions have demonstrated significant high nutritional content as compared to introduced accessions; therefore it is necessary to focus more on traits of locally adapted genotypes in Amaranthus species crop improvement programs. The findings have also shown that Amaranth genotypes studied can make significant nutritional contribution to recommended human dietary intakes and consequently can contribute to improvement of the nutritional status of Malawians.

\section{Acknowledgements}

We wish to express our acknowledgements to Ministry of Agriculture and Food Security for supporting Nathan Kachiguma during his MSc studies and Global Environment Facility through the UNDP for financially supporting the research. Kenya Agriculture Research Station and Chitedze Agriculture Research Station are also acknowledged for providing some of the accessions.

\section{References}

Akubugwo, I. E., Obasi, N. A, Chinyere, G. C., \& Ugbogu, A. E. (2007). Nutritional and chemical value of Amaranthus hybridus L. leaves from Afikpo, Nigeria. African Journal of Biotech, 6(24), 2833-2839.

Ali, A. (2009). Proximate and mineral composition of the Marchubeh (Asparagus officinalis). World Dairy and Food Science, 4(2), 142-149.http://dx.doi.org/10.5539/jfr.v1n3p214

Anjali, K., Joshi, A., Maloo, S. R., \& Sharma, R. (2013). Assessment of the morphological and molecular diversity in Amaranthus spp. African Journal of Agric. Research, 8(19), 2307-2311.

AOAC. (1997). Official Method of Analysis of AOAC International (16 ${ }^{\text {th }}$ Edition). Association of Vitamin Chemists Inc. 1951. Methods of Vitamin Assay. $2^{\text {nd }}$ ed. Inter-science Publishers, Inc. New York. 
Asaolu, S. S., Adefeni, O. S., Oyakilome, I. G., Ajibulu, K. E., \& Asaolu, M. F. (2012). Proximate and Mineral Composition of Nigerian Leafy Vegetables. Journal of Food Research, 1(3), 214-218. http://dx.doi.org/10.5539/jfr.v1n3p214

Barakat, M. Z., Shehab, S. K., Darwish, N., \& Zahermy, E. I. (1973). Determination of Ascorbic Acid from plants. Analyst Biochemistry, 53, 225-245.

Chitsulo, G. (2013). Determination of Nutritive Value of Selected Indigenous Vegetables: A Case Study Of Indigenous Vegetables Released by the Indigenous Vegetable Project at Bunda. BSc Food Nutrition report. Bunda College of Agriculture.

Erum, S., Ambreen, F., Naeemullah, M., Masood, S., Qayyum, A., \& Rabbani, M. A. (2012). Genetic divergence in Amaranthus Collected from Pakistan. The Journal of Animal \& Plant Sciences, 22(3), 653-658.

Horwitz, W. (2000). Official Method of Analysis of AOAC International (17 $7^{\text {th }}$ Edition). OAC International. Maryland, USA.

Janovska, D., Cepkova, P. H., \& Dzunkova, M. (2012). Characterization of the Amaranthus Genetic Resources in the Czech Gene Bank.Genetic Diversity of Plants, Mahmut Caliskan (Ed). In Tech, 457-478.

Kehinde, T. O., Ajala, M. O., Daniel, I. O., \& Oyelakin, O. O. (2013). Physiological and Genetic Integrity of Amaranth (Amaranthus spp.) Seeds during Storage. International Journal of Plant Breeding and Genetics, 7(1), 35-46. http://dx.doi.org/10.3923/ijpbg.2013.35.46

Kruger, M., Sayed, N., Langenhoven, M., \& Holing, F. (1998). Composition of South African Foods: vegetables and Fruit. Research Institute for Nutritional Diseases, South African Medical Research Council. (pp. 2-39). South Africa.

Kwapata, M. B., Dawa, G., \& Maliro M. F. A. (1992). Growth and Yield Performance of Vegetable Amaranth Varieties in Contrasting Agroecological Zones. Afric Crop Sci Conference Proceedings, Pretoria, 13-17 January 1997. African Crop Science Society, Makerere University. Kampala, Uganda. 3, 819-823

Kwapata, M. B., \& Maliro, M. F. A. (1995). Indigenous Vegetables in Malawi: Germplasm collection and Improvement of production practices. In L. Guarino (Ed.). Traditional African Vegetables: proceedings of the IPGRI International Workshop of Genetic Resources of Traditional Vegetables in Africa (pp. 132-135). Conservation and Use. IPGRI, Kenya,

Lenntech, B. V. (2013). Recommended Daily Intake of Vitamins and Minerals. Rotterdamseweg. Netherlands.

Makobo, N. D., Shoko, M. D., \& Mtayira, T. A. (2010). Nutrient Content of Vegetable Amaranth (Amaranthus cruentus L) at Different Harvesting Stages. World Journal of Agriculture Sciences, 6(3), 285-289.

Maundu, P., Ngugi, G., \& Kabuye, C. H. (1999). Traditional Food plants of Kenya. Kenya resource Centre for Indigenous Knowledge, National Museum of Kenya, Nairobi.

Mohammed, M. I., \& Sharif, N. (2011). Mineral Consumption of Some Leafy Vegetables Consumed in Kano, Nigeria. Journal of Basic and Applied Science, 19(2), 208-212.

Nielsen, S. S. (2003). Food Analysis ( ${ }^{\text {rd }}$ Ed.)New York: Kluwer Academic/Plenum publishers.

O'Brien, G. K., \& Price, M. L. (2008). Amaranth grain and vegetable types. ECHO Technical note, 2, 1-9.

Pandey, R. M., \& Singh, R. (2010). Geneticstudies for biochemical and quantitative characters in grain amaranth (Amaranthus hypochondriacus L.). Plant Omics Journal, 3(4), 129-134.

Patricia, O., Zoue, L., Megnanou, R., Doue, R., \& Niamke, S. (2014). Proximate Composition and Nutritive Value of Leafy Vegetables Consumed in Northern Cote D'ivoire. European Scientific Journal, 10, 212-227.

Shahidi, F., Chavan, U. D., Bal, A. K., \& Mckenzie, D. B. (1999). Chemical Composition of Beach Pea (Lathyrus maritimus L.) Plant parts. Food Chemistry, 64(1), 39-44. http://dx.doi.org/10.1016/S0308-8146 (98) 00097-1

Sharma, N., Gupta, P. C., \& Rao, C. V. (2012). Nutrient Content, Mineral Content and Antioxidant Activity of Amaranthus viridis and Moringa oleifera leaves. Research Journal of Medicinal Plants, 6, 253-259. http://dx.doi.org/10.3923/rjmp.2012.253.259

Silva, H. P., Scoles, G. E., \& Covas, G. F. (2000). Integral Chemical Analysis of the Amaranth (Amaranthus greggii S. Wats). College of Exact and Natural Resources. Argentina.

World Health Organization \& Food Agriculture Organization of the United Nations. (2004). Vitamin and mineral 
requirements in human nutrition: report of the joint FAO/WHO expert consultant $\left(2^{\text {nd }}\right.$ ed $) 21-30^{\text {th }}$ September, 1198. Bangkok, Thailand.

World Health Organization. (2012). Guidelines: Potassium intake for adults and children. WHO. Geneva.

World Health Organization. (2013). Guidelines: Calcium supplementation in pregnant women. WHO. Geneva.

\section{Copyrights}

Copyright for this article is retained by the author(s), with first publication rights granted to the journal.

This is an open-access article distributed under the terms and conditions of the Creative Commons Attribution license (http://creativecommons.org/licenses/by/3.0/). 